\title{
Aplikasi Pengacak Soal Ujian Untuk Type Soal Berbasis Microsoft Word Menggunakan Metode Linear Congruent Method (LCM)
}

\author{
1)Tonni Limbong \\ UNIKA Santo Thomas Medan, Jl. Setiabudi No.479 Medan, Sumatera Utara, Indonesia \\ http : // www.ust.ac.id, Email: tonni.budidarma@gmail.com
}

${ }^{2)}$ Insan Taufik

STMIK Pelita Nusantara, Jl. Iskandar Muda No. 1 Medan, Sumatera Utara, Indonesia http : // www.penusa.ac.id, Email: insan.taufik@gmail.com

\begin{abstract}
Exam questions made by lecturers in general in an educational institution around $99 \%$ are made from Microsoft Word applications. This happens because of the ability or skill of the question maker and the facilities of the institution. The exam questions that have been made seem like a consumable model, even though the material from these questions still has a relationship with the subject. With this condition the existing questions are not necessary and do not have to be destroyed, it should be stored and made into a question bank. So on the next examination the test questions stored in the bank questions to be randomized again to make new questions as many as the number of questions needed so that the exam questions are presented far from static and color and each test for each participant will never be the same as previous questions. and also the implementation of semi-computerized exams do not need to require a computer laboratory.

This application is equipped with a randomization method, namely Linear Congruent Method (LCM), so that the questions that appear will never be the same each time printing a question in the form of executable (EXE), making it easier for study programs to make exam questions in multiple choices and in accordance with existing material in the syllabus and GBPP that apply from several lecturers who teach the same subject.
\end{abstract}

Keywords: Question Bank, Random Question Exam, Problem Random Application, LCM

\section{PENDAHULUAN}

Pendidikan adalah pembelajaran pengetahuan, keterampilan, dan kebiasaan sekelompok orang yang diturunkan dari satu generasi ke generasi berikutnya melalui pengajaran, pelatihan, atau penelitian. Pendidikan sering terjadi di bawah bimbingan orang lain, tetapi juga memungkinkan secara otodidak. Setiap pengalaman yang memiliki efek formatif pada cara orang berpikir, merasa, atau tindakan dapat dianggap pendidikan. Pendidikan umumnya dibagi menjadi tahap seperti prasekolah, sekolah dasar, sekolah menengah dan kemudian perdosenan tinggi, universitas atau magang.

Menurut UU No. 20 tahun 2003 Pendidikan adalah usaha sadar dan terencana untuk mewujudkan suasana belajar dan proses pembelajaran agar peserta didik secara aktif mengembangkan potensi dirinya untuk memiliki kekuatan spiritual keagamaaan, pengendalian diri, kepribadian, kecerdasan, akhlak mulia, serta ketrampilan yang diperlukan dirinya, masyarakat, bangsa, dan Negara.
Sedangkan pengertian pendidikan menurut $\mathrm{H}$. Horne, adalah proses yang terus menerus (abadi) dari penyesuaian yang lebih tinggi bagi makhluk manusia yang telah berkembang secara fisik dan mental, yang bebas dan sadar kepada vtuhan, seperti termanifestasi dalam alam sekitar intelektual, emosional dan kemanusiaan dari manusia.

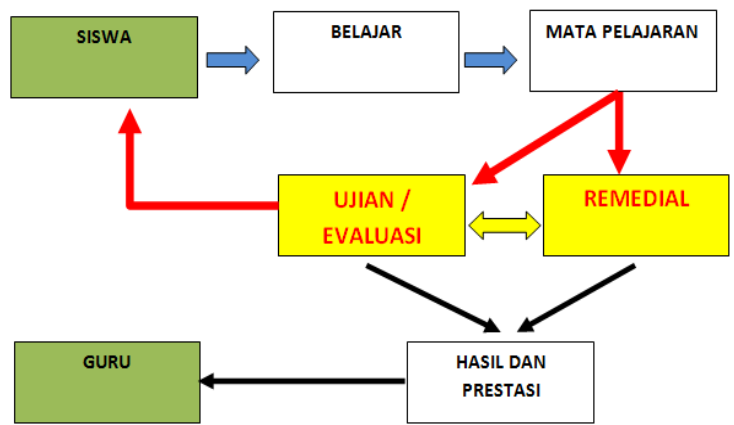

Gambar 1. Bagan Alir Proses Kegiatan Belajar Mengajar (KBM)

Soal adalah alat untuk mengujian pengetahuan mahasiswa. Topik tersusun dari beberapa soal yang digunakan untuk menilai pemahaman mahasiswa atas materi tersebut. 
Soal merupakan suatu tolak ukur yang digunakan untuk mengukur kemampuan mahasiswa. Saat seseorang mengerjakan soal, dia akan berusaha menjawabnya dengan benar. Mahasiswa yang mengerjakan soal ada yang menjawabnya dengan tepat, dan ada pula yang salah. Dari hasil tersebut dapat diketahui kemampuan masing-masing mahasiswa mengenai seberapa paham mahasiswa tersebut terhadap materi yang telah di ajarkan. Dari hal tersebut, dapat kita ketahui bahwa setiap mahasiswa memiliki kemampuan yang berbeda-beda. Mengerjakan soal ibaratnya menghadapi sebuah miniatur kehidupan. Tetapi, ada satu hal yang harus diingat bahwa soal tidak sama dengan kehidupan ${ }^{[3]}$.

Masalah yang ditemukan saat ini adalah dimana kemampuan membuat soal oleh para guru dalam sebuah lembaga pendidikan sekitar 99\% mampu mengoperasikan aplikasi Microsoft Word dalam membuat soal ujian. Ini terjadi karena kemampuan atau skill dari pembuat soal tersebut dan fasilitas dari lembaga tersebut. Soal ujian yang selama ini dibuat sepertinya model habis pakai, padahal materi dari soal tersebut tetap masih ada hubungan dengan bidang studi dari mata kuliah. Dengan kondisi ini soal yang ada tidak perlu dan tidak harus dimusnahkan, sebaiknya disimpan dan dijadikan pada pelaksanaan ujian berikutnya bank soal untuk membuat soal yang baru sebanyak jumlah soal yang dibutuhkan sehingga soal ujian yang tidak akan pernah sama dengan soal-soal sebelumnya.

Hal ini akan membantu kualitas dari soal yang baru karena tidak akan sama dengan soal yang lalu dan juga tidak akan pernah sama dengan soal yang akan datang, soal juga akan makin kaya jika bank soal dibuat.

Adapun rumusan masalah dalam penelitian ini adalah: 1). Bagaimana Algoritma atau langkah-langkah yang tepat untuk mengacak soal Microsoft Word tanpa harus di inputkan kedalam database. 2). Bagaimana menerapkan metode Linear Congruent Method (LCM) untuk mengacak Soal ujian yang dibuat dari Microsoft Word. 3). Bagaimana merancang aplikasi merancang pengacak soal ujian Microsoft Word menggunakan metode Linear Congruent Method

Berdasarkan keterangan di atas maka sudah seharusnya dibangun sebuah aplikasi dari komputer yaitu Aplikasi Pengacak Soal Ujian Type Dokumen Microsoft Word, yang nantinya dipergunakan untuk mengacak soal ujian lembaga atau instansi pelaksana ujian termasuk kampus dan sekolah. Dimana soal tersebut di simpan di folder dalam bentuk dokumen microsoft word dengan menggunakan format pembuatan soal yang ditentukan agar aplikasi dapat mengacak soal tersebut dengan sempurna.

\section{TINJAUAN PUSTAKA}

\subsection{Penelitian Terdahulu}

Penelitian skripsi Program Studi Sistem Informasi di Universitas Jember dengan judul Sistem Ujian TOEFL Dengan Pengacakan Soal Menggunakan Algoritma Fisher Yates, mengemukakan bahwa sistem ujian TOEFL yang dinamis (memiliki banyak variasi kode soal). Metode pengacakan soal Fisher Yates tidak hanya dapat diterapkan pada sistem ujian TOEFL namun juga dapat diterapkan misalnya pada sistem ujian penerimaan pegawai, sistem ujian akhir dengan syarat kriteria soal yang jelas (pembobotan soal jelas). Metode ini akan mempermudah pembuatan kode soal pada sistem ujian ${ }^{[3]}$.

Penelitian terdahulu dengan judul Implementasi Linier Congruent Method Untuk Pengacakan Soal Ujian Pada Aplikasi Belajar Hiragana, pada jurnal edukomputika semarang, mengemukakan bahwa penerapan mengimplementasikan linear congruent method untuk pengacakan soal ujian pada aplikasi beleajar hiragana. Metode pengembangan perangkat lunak yang digunakan adalah dengan memodifikasi metode waterfall, maka langkah-langkah penelitian ini antara lain persiapan penelitian, analisis perangkat lunak, analisis perangkat keras dan perangkat lunak yang digunakan, desain/perancangan perangkat lunak, implementasi (kode), dan pengujian perangkat lunak. Linear congruent method telah berhasil diimplementasikan dalam aplikasi belajar hiragana untuk pengacakan soal ujian dan pilihan jawaban pada ujian tebak suara dan menulis kata ${ }^{[4]}$.

Penelitian terdahulu oleh pada Prosiding seminar Nasional Ilmu Komputer 2015 (SNIKOM 2015) di Aptikom wilayah I SumutNAD, dengan judul Implementasi Linear Congruent Method (LCM) Untuk Pengacakan Soal Ujian Berkategori, mengemukakan bahwa Ujian adalah tes yang bertujuan untuk menentukan kemampuan seorang murid, mahasiswa atau calon pekerja. Biasanya ujian tes bentuknya tertulis, walaupun beberapa mungkin praktek atau komponen praktis, dan sangat bervariasi dalam struktur, isi dan kesulitan tergantung pada subjek, kelompok usia orang yang diuji dan profesi. Soal ujian yang disajikan kepada para peserta ujian dan dalam pencapian hasil yang optimal maka perlu menyajikan soal ujian dalam bentuk pengelompokan/kategori seperti : Mudah, 
Sedang, Sulit dan dalam pelaksanaan ujian, tiap peserta ujian akan mendapatkan soal ujian yang berbeda antara masing-masing peserta ujian tersebut ${ }^{[5]}$.

\subsection{Pengertian Ujian}

Ujian sebenarnya adalah alat ukur untuk mengukur keberhasilan belajar seseorang siswa. Layaknya alat ukur,Ujian juga harus memilki akurasi dan presisi.Misalkan saja sebuah penggaris yang merupakan alat ukur panjang.Penggaris yang baik haruslah dapat mengukur panjang bukan mnegukur berat dan penggaris yang baik harus pula mempunyai skala yang selalu tetap sehingga dapat menunjukan hasil pengukuran yang sama untuk tiap pengukuran pada benda yang sama.

\subsection{Pengertian Bank Soal}

\subsubsection{Bank soal}

Dalam literatur berbahasa Inggris istilah Bank Soal berarti item bank yang berarti "bank butir". Hal ini berarti bank soal adalah berisi butir-butir soal tes maupun butir penyataan angket. Bank soal bermanfaat untuk mengatasi guru tatkambil soal yang diperlukan apabila guru tala akan melakukan penilaian. Guru tinggal mengambil butir soal yang telah tersimpan. Menurut Ward dan Ward (2004), " a item bank is a collection of test items that may be easily accessed for use in preparing examinations". Bank soal adalah koleksi butir soal yang sudah dipergunakan untuk menyiapkan sebuah penilaian. Menurut Grounlund, dalam Rudner adalah bank soal adalah sekumpulan soal yang layak yang dikodekan berdasarkan subjek materi, tingkat pembelajaran, tujuan pembelajaran yang diukur, dan bermacam karakteristik lain butir soal yang berguna. menurut Sumardyono dalam hand out diklat in on in Pengembangan Keprofesian Berkelanjutan, menyimpulkan bahwa bank soal berarti sekelompok butir soal terkalibrasi (teruji) baik secara teoritis maupun empiris dan memuat informasi penting sehingga dapat dengan mudah dipergunakan dalam penyusunan sebuah instrumen penilaian (tes).

Bank soal bukan hanya bank pertanyaan, pool soal, kumpulan soal, gudang soal, atau perpustakaan soal (Millman and Arter, 1984: 315); melainkan bank yang butirbutir soal terkalibrasi (Wright and Bell, 1984: 331) dan disusun secara sistematis agar memudahkan penggunaan kembali dan manfaat soalnya. Untuk itu butir-butir soal di dalam bank soal harus tersedia untuk setiap standar kompetensi dan kompetensi dasar pada setiap mata pelajaran, tingkat kesukaran butir soal, dan jenjang pendidikan. Hal ini sangat diperlukan untuk memiliki suatu tujuan yang jelas sebagai panduan dan pengembangan bank soal.

\subsubsection{Karakteristik Bank Soal}

Karakteristik Bank soal karakteristik bank soal: a). Setiap butir soal pada bank soal merupakan butir soal yang terkalibrasi (teruji), soal-soal disebut layak (suitable) mengandung pengertian soal berkualitas, baik validitas (validity), keterbacaan (realiability), keterukuran (measurable) maupun aspek ekonomisnya (efisien, lugas) b).Setiap butir soal dilengkapi berbagai informasi berguna. Setiap butir soal pada bank soal memiliki informasi yang bermanfaat dalam penyususunan sebuah instrumen penilaian. $\mathrm{c}$ ). Database (soal-soal) pada sebuah bank soal dibangun secara terstruktur.anaan Bank soal bukan merupakan kumpulan soal saja namun merupakan suatu organisasi soal di mana antar soal satu dengan yang lain mempunyai link atau hubungan berdasarkan komponen spesifikasi yang sama ${ }^{[8]}$.

\subsubsection{Prosedur Pengembangan Soal}

Butir-butir soal yang akan disimpan di dalam bank soal harus diproses melalui prosedur pengembangan bank soal. Prosedur pengembangan butir soal yang digunakan di dalam pengembangan bank soal adalah :(1) Penyusunan kisi-kisi, (2) Penulisan butir soal, (3) Revisi/validasi butir, (4) Perakitan tes, (5) Uji coba tes, (6) Memasukkan data, (7) Analisis butir soal secara klasik dan IRT, (8) Menyeleksi butir untuk bank soal yang terkalibrasi ${ }^{[9]}$.

Dalam mengolah butir-butir soal dalam bank soal diperlukan perangkat lunak yang tepat. Secara singkat, perangkat lunak yang digunakan memiliki tiga kelebihan, yaitu : (1) Kemudahan pada penyimpanan dan pencarian kembali, (2) Kesanggupan untuk memunculkan kembali grafik butir-butir secara tepat, (3) Kelengkapan susunan data butir soal.

\subsection{Pengertian Aplikasi}

Aplikasi adalah Program siap pakai yang dapat digunakan untuk menjalankan perintahperintah dari pengguna aplikasi tersebut dengan tujuan mendapatkan hasil yang lebih akurat sesuai dengan tujuan pembuatan aplikasi tersebut, aplikasi mempunyai arti yaitu pemecahan masalah yang menggunakan salah satu tehnik pemrosesan data aplikasi yang biasanya berpacu pada sebuah komputansi yang diinginkan atau diharapkan maupun pemrosesan data yang diharapkan ${ }^{[7]}$.

\footnotetext{
Aplikasi Pengacak Soal Ujian Untuk Type Soal Berbasis Microsoft Word Menggunakan 
Aplikasi adalah penggunaan dalam suatu komputer, instruksi (instruction) atau pernyataan (statement) yang disusun sedemikian rupa sehingga komputer dapat memproses input menjadi output ${ }^{[1]}$.

\subsection{Pengacakan Soal}

Berfungsi untuk menampung soal, melakukan pengacakan, melakukan pemaketan, melakakuan analisi butir soal dari setiap mata pelajaran yg diujikan. Sistem bank soal ini mengakomodir secara detail level yang akan dicapai mulai kompetensi utama, kompetensi inti, standar kompetensi (SK), kompetensi dasar (KD), indikator esensial dan level taksonomi yang akan dicapai. Sistem ini dapat menyediakan soal ujian dalam bentuk digital untuk keperluan ujian online dan juga dapat menyediakan soal versi cetak untuk keperluan ujian versi manual. Krn berada dalam suatu sistem maka soal ini dapat distribusikan secara 'digital' sesuai dengan kebutuhan.

Sebagai gambaran singkat bagaimana bank soal menyediakan variasi soal ujian, jika setiap mata pelajaran menyediakan 1000 butir dan 100 butih dipilih untuk diujikan, setiap butir soal menyediakan 5 pilihan jawaban. Maka variasi soal yang kemungkinan muncul adalah $1000 \times 100 \times 5=500.000$ variasi, saya yakin 'pelaku kecurangan' akan kesulitan membuat kunci jawaban generik seperti pada umumnya. Kalaupun bisa harus mengulas/membuat kunci jawaban 1000 butir soal tersebut ${ }^{[10]}$.

\subsection{Linear Congruent Method}

Menentukan pengacakan soal berkategori menggunakan metode Linear Congruent Method adalah dengan menggunakan rumus $X$ $=(\mathrm{a} \cdot \mathrm{x}+\mathrm{b})$ mod $\mathrm{M}$ pada aplikasi yang akan digunakan dengan keterangan $X=$ bilangan acak $k e-i, a=$ faktor penggali, $x=$ bilangan acak sebelumnya, $b=$ increment, dan $M=$ Modulus. Dengan membangkitkan rumus maka akan dapat hasil pengacakan soal tanpa adanya soal yang sama muncul kembali ${ }^{[11]}$.

LCM memanfaatkan model linieruntuk membangkitkan bilangan acak yang didefinisikan sebagai berikut $X=(a \cdot x+b)$ $\bmod \mathrm{M}$

Dimana $: X=$ bilangan acak ke-i

$a=$ Faktor Penggali

$\mathrm{X}=$ bilangan acaksebelumnya

$b=$ increment

$\mathrm{M}=$ Modulus

Sebagai Contoh, untuk mengacak bilangan sebanyak 8 kali, di mana nilai $a=11$, $\mathrm{b}=25, \quad \mathrm{~m}=26$ dan $\mathrm{X}(0)=3$ adalah sebagai berikut :

1. $X(1)=(11(3)+25) \bmod 26=6$

2. $X(2)=(11(6)+25) \bmod 26=13$
3. $X(3)=(11(13)+25) \bmod 26=12$

4. $X(4)=(11(12)+25) \bmod 26=1$

5. $X(5)=(11(1)+25) \bmod 26=10$

6. $\quad X(6)=(11(10)+25) \bmod 26=21$

7. $\quad X(7)=(11(21)+25) \bmod 26=22$

8. $X(8)=(11(22)+25) \bmod 26=11$

9. $\quad X(8)=(11(11)+25) \bmod 26=16$

10. $X(8)=(11(16)+25) \bmod 26=19$

Maka, bilangan acak yang dibangkitkan adalah :

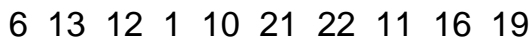

Dari contoh di atas dapat diketahui bahwa dalam pembangkitan bilangan acak tidak terjadi perulangan.

Langkah awal yang dikerjakan adalah Pengumpulan data dan menganalisa guna menyeragamkan semua bentuk soal baik berbentuk gambar dan teks yang dibuat dari microsoft word dengan tipe soal pilihan ganda, dan melakukan sosialisasi tentang teknik pembuatan soal agar nanti dapat dibaca dengan sempurna oleh sistem dan aplikasi, dan juga agar semua fungsi dalam bahasa pemrogramannya berjalan optimal. Hasil penelitian dipublikasi pada jurnal ilmiah lokal. Metode pengacakan yang dipakai dalam mengacak soal adalah LCM guna untuk meminimalkan orang lain dapat menghitung dan menebak soal yang mana akan muncul pada soal ujian dari bank soal tersebut.

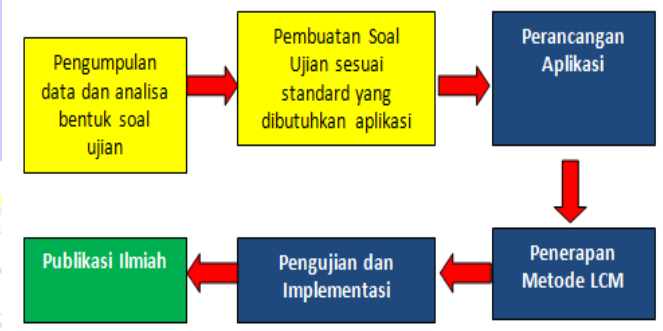

Gambar 2. Roadmap Penelitian Aplikasi Pengacakan Soal Ujian type dokumen Microsoft Word dengan Metode LCM

\section{METODE PENELITIAN}

Metode penelitian sesuai dengan Research and Development menurut Borg and Gall (2003) dan penelitian dilakukan di Unika Santo Thomas dalam 3 (tiga) tahapan, yaitu tahap pertama tentang masalah pengumpulan data /analisa sampai perancangan dan tahap masalah uji coba dan sosialisi penerapan aplikasi.

\subsection{Tahapan Penelitian}

Penelitian akan dilakukan di Unika Santo Thomas SU Medan yakni Program studi Teknik Informatika (S1) dan Sistem Informasi (S1). Penelitian ini dilakukan selama 6 (enam) bulan dengan tahapan yaitu:

a. Tahap Identifikasi / Analisis

Aplikasi Pengacak Soal Ujian Untuk Type Soal Berbasis Microsoft Word Menggunakan 


\section{Tahap 1 : Studi Literatur}

Rencana kegiatan adalah melakukan kajian literatir untuk penguatan teori tentang soal, pengadaan dan ujian dengan kejadian yang rill dilapangan dalam hal ini objek penelitiannya ada di Unika Santo Thomas SU Medan. Observasi di program studi dan interview terhadap pihak program studi, dosen, maupun Fungsionaris tentang aturan dan type soal ujian.

\section{Tahap 2: Studi Explorasi}

Rencana kegiatan ini untuk pengembangan sistem sesuai dengan kebutuhan dan fakta di lapangan dengan cara menganalisa kebutuhan apa yang dilakukan untuk pembuatan bank soal dalam hal ini soal yang diacak adalah soal bertype Doc dan Docx yang selama ini semua dosen diwajibkan membuat soal yang berbeda untuk tiap kelas. Disini harus ditemukan fakta yang sebenarnya bahwa setiap dosen membuat soal tersebut dalam bentuk microsoft word bukan dalam bentuk tabel database, untuk hal ini sudah seharusnya di racang sebuah aplikasi yang dapat membaca soal microsoft word yang langsung bisa di konversi ke database dan disini operator atau EDP tidak perlu mengetik ulang lagi soal yang ada dan juga operator atau dosen tidak lagi melakukan pemilihan soal -soal yang mana harus di keluarkan. Setelah itu semua fakta literatur dan temuan dilapangan dibuatlah proposal untuk kegiatan penelitian tersebut.

\section{b. Analisa dan Perancangan}

Tahap 1 : Analisis Model Pengacakan Soal Dan Bank Soal

Data yang diperoleh akan dianalisis sesuai dengan kebutuhan dan keadaan data untuk pemanfaatan. Analisis ini meliputi mengidentifikasikan dan mengevaluasi permasalahan, kesempatan, hambatan yang terjadi dan kebutuhan yang diharapkan sehingga dapat diusulkan perbaikan. Permasalahan yang ditemukan dasar perancangan sistem yang dikembangkan. yaitu untuk mengacak soal ujian dengan type dokumen microsoft Word tanpa menginput soal dalam bentuk database.

\section{Tahap 2 : Perancangan Aplikasi Bank Soal Dan Pengacakan Soal}

Menentukan rancangan aplikasi Aplikasi Bank Soal dan Pengacakan Soal Ujian Type Document Microsoft Word, Rencana kegiatan pada tahap ini adalah:
1. Perancangan proses

Perancangan proses dilakukan dengan Diagram kontex.

2. Perancangan flowchart

Perancangan flowchart merupakan langkah prosedur penyelesaian masalah yang diekspresikan dengan simbol grafis yang baku.

3. Perancangan Aplikasi

Perancangan aplikasi merupakan tahapan atau tampilan yang akan dimunculkan ketika program dijalankan dan mengambarkan hubungan antar tiap elemen dalam sebuah sistem agar menghasilkan informasi.

4. Perancangan interface

Perancangan interface merupakan tahapan untuk membangun bentuk muka pemakai dengan sistem dalam menjalankan aplikasi, sehingga pengguna mudah menggunakannya. Perancangan interface ini meliputi perancangan input dan output yang diperlukan untuk menentukan bentuk masukan dan keluaran seperti gambar 3 . berikut ini:

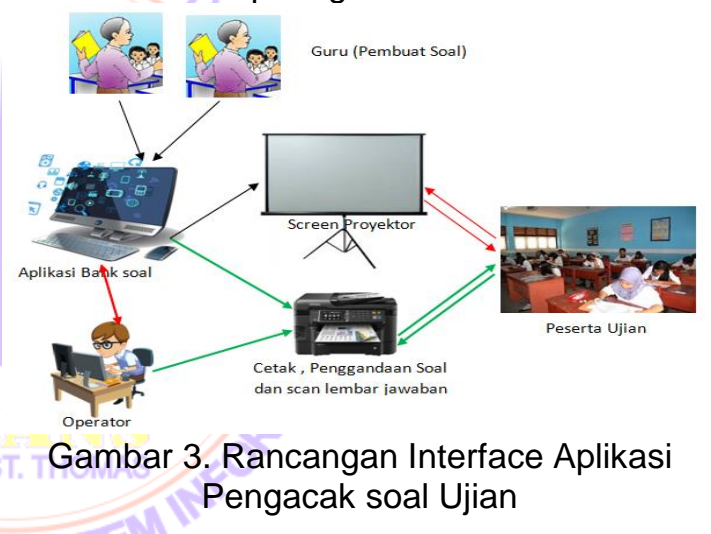

\subsection{Bagan Aliran Penelitian}

Untuk memudahkan pelaksanaan penelitian sebaiknya setiap pekerjaan disusun secara bertahap dalam bentuk diagram seperti gambar 4. berikut ini :

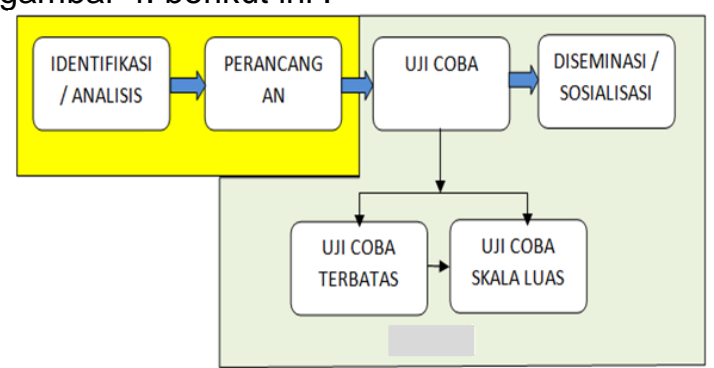

Gambar 4. Diagram Metode Penelitian

Research and Development oleh Borg and Gall (2003)

\section{HASIL DAN PEMBAHASAN}

Aplikasi ini dibuat untuk menyelesaikan permasalahan umum yang berhubungan 
degan pengacakan soal ujian. Pada awalnya soal ujian diacak menggunakan teknik manual (copy-paste), akan tetapi metode ini akan sangat sulit dijalankan apabila jumlah soal yang diacak sangat banyak. Apabila dipaksakan akan membutuhkan waktu dan usaha yang sangat tidak efisien, mengingat pengacakan soal adalah hal yang wajib pada instansi yang mempunyai tingkat penilaian yang tinggi terhadap peserta ujian.

Aplikasi Pengacak Soal Ujian Dokumen Word pada versi ini tidak mendukung fasilitas penomoran otomatis (bullet numberin), pada penomoran soal. Tetapi untuk penomoran jawaban, fasilitas ini tidak bermasalah malahan pada bagian selain nomor soal, maka diwajibkan menggunakan penomoran otomatis (terkecuali bukan nomor, Misal : a. b. c. d.; dll). Berikut hal-hal umum yang harus diketahui :

1. Untuk penomoran setiap soal yang ada tidak boleh menggunakan bullet and numbering, akan tetapi diwajibkan untuk mengetikan nomor soal manual.

2. Untuk penomoran selain soal (mis: jawaban, bagian soal, header) maka harus menggunakan bullet and numbering.

3. Kesalahan penomoran pada soal akan berdampak soal tidak akan terdeteksi aplikasi. Maka harus diperbaiki terlebih dahulu.

4. Soal minimal yang ada adalah 2 (dua) soal.

1. Format Header

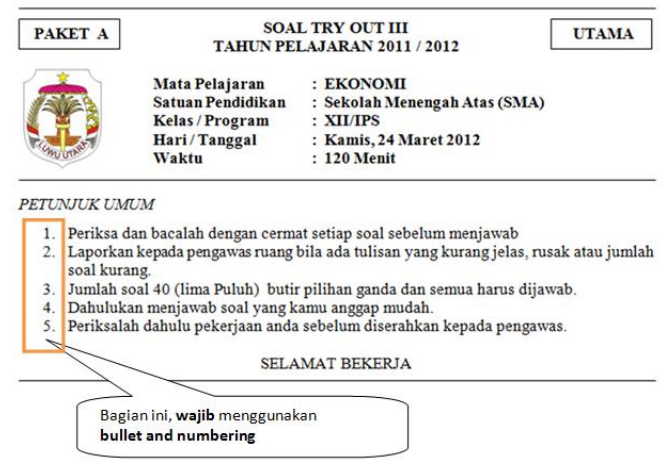

Gambar 5. Tampilan Pembuatan Footer

Header adalah bagian pembuka, sebelum soal mulai di buat. Biasanya bagian ini berisi informasi instansi yang mengadakan ujian, waktu, tempat dan informasi lainnya mengenai ujian tersebut.

Defenisi Paragraph adalah "Setiap kali menekan tombol enter ketika pengetikkan (walaupun kosong), maka hal itu disebut paragraph" Jadi, untuk selain soal, maka pada awal paragraph tidak boleh menggunakan angka, diperbolehkan akan tetapi menggunakan bullet and numbering.

\section{Format Soal}

Untuk format nomor soal, diketikkan secara manual

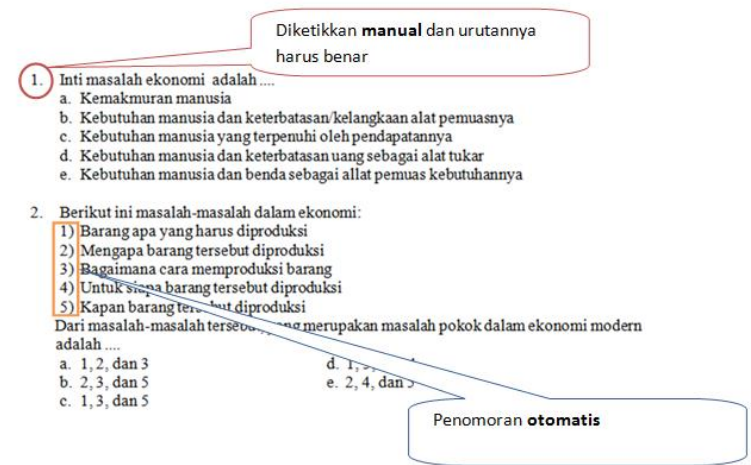

Gambar 6. Tampilan Format Soal

Sedangkan untuk jarak antara soal sebaiknya tidak menggunakan "Enter", tetapi menggunakan line spacing. Dengan cara :

1. Seleksi satu buah soal (hanya bagian atasnya saja)

1. Inti masalah ekonomi adalah....

a. Kemakmuran manusia

b. Kebutuhan manusia dan keterbatasan/kelangkaan alat

c. Kebutuhan manusia yang terpenuhi oleh pendapatanny

d. Kebutuhan manusia dan keterbatasan uang sebagai ala1

e. Kebutuhan manusia dan benda sebagai allat pemuas ke

2. Berikut ini masalah-masalah dalam ekonomi:

1) Barang apa yang harus diproduksi

2) Mengapa barang tersebut diproduksi

3) Bagaimana cara memproduksi barang

4) Untuk siapa barang tersebut diproduksi

5) Kapan barang tersebut diproduksi

Dari masalah-masalah tersebut, yang merupakan masalah adalah .
a. 1,2 , dan 3
d. 1,3 , dan 4

Gambar 7. Tampilan Format Sỏal Pembuatan Jarak

2. Klik line spacing $\stackrel{\uparrow}{\downarrow}$, kemudian pilih Add Space Before Paragraph.

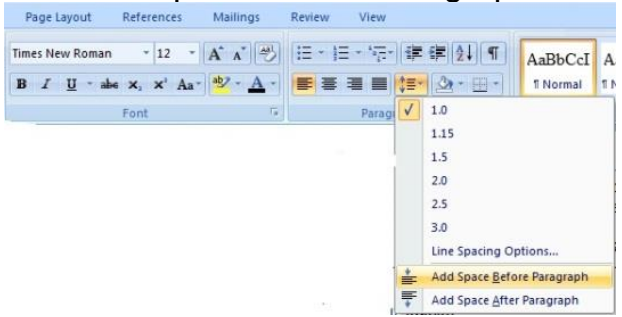

Gambar 8. Tampilan Menu Line Spacing

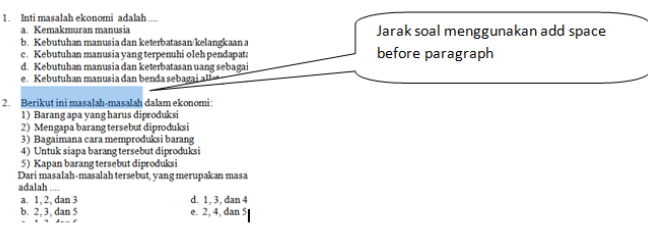

Gambar 9. Tampilan batas antar Soal 
ISSN : 2548-6985

\section{Format Jawaban}

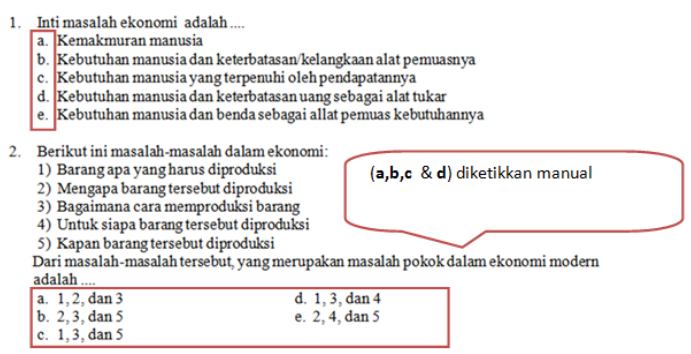

Gambar 10. Tampilan Format Pembuatan Jawaban

\section{Footer Soal Ujian}

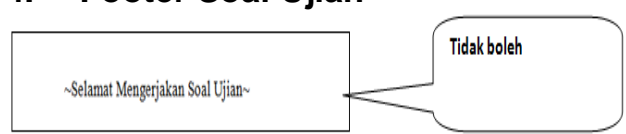

Gambar 11. Tampilan Format Footer Soal Ujian

Untuk kata-kata penutup yang biasa digunakan pada soal ujian, tidak boleh digunakan. Apabila harus maka, kata-kata ini dibuat setelah proses soal sudah selesai diacak pada aplikasi.

\section{Tampilan Aplikasi untuk mengolah SOAL}

\section{TUNGGAL}

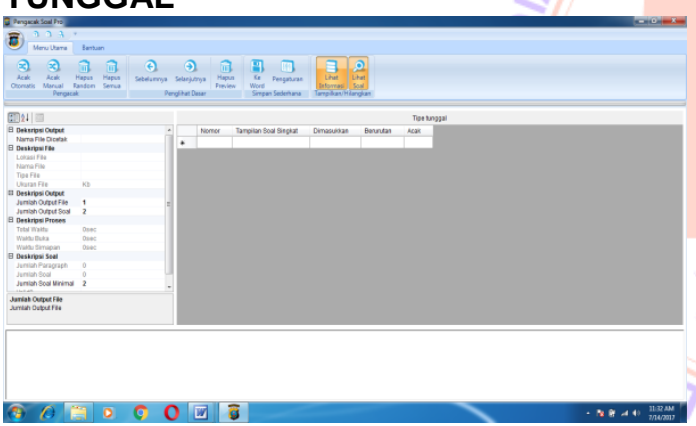

Gambar 12. Tampilan Aplikasi Soal Tunggal

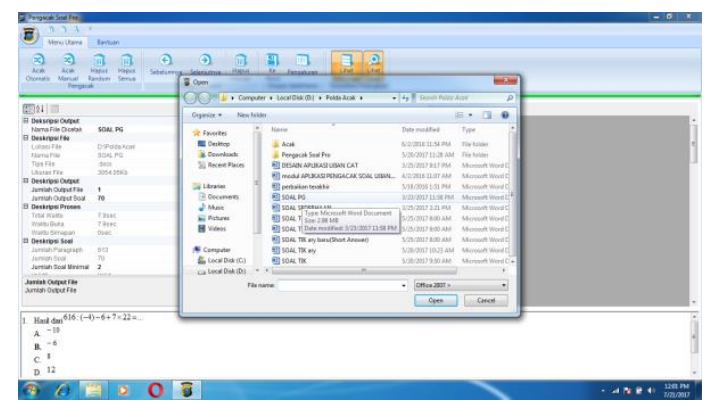

Gambar 13. Tampilan Aplikasi Untuk Browse Soal Ms Word

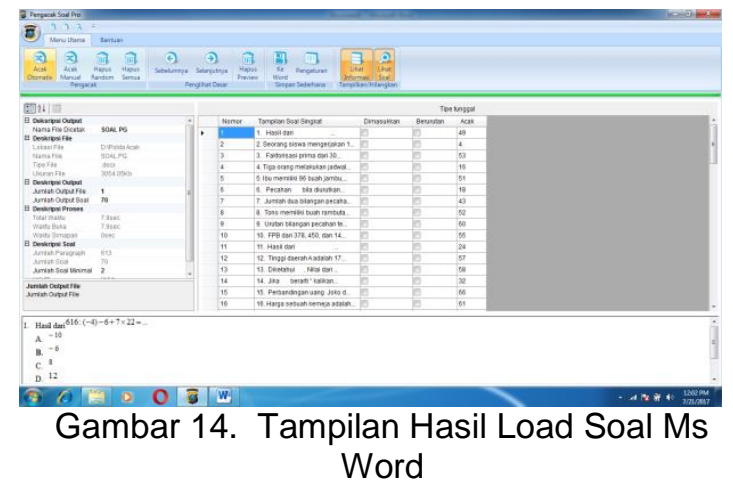

Tampilan Aplikasi untuk mengolah SOAL BERTIPE

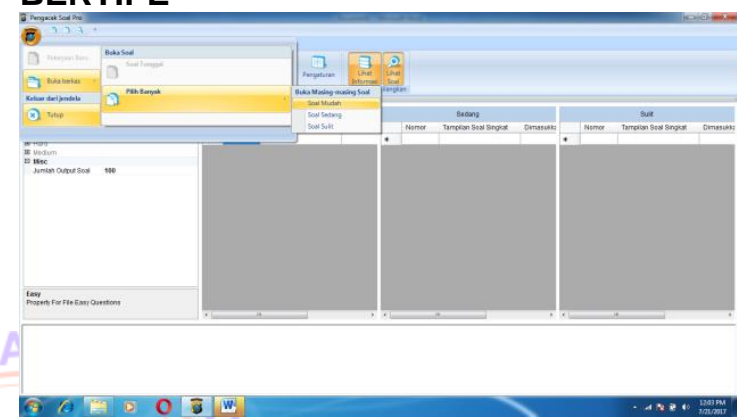

Gambar 15. Tampilan Hasil Menu Soal Bertipe

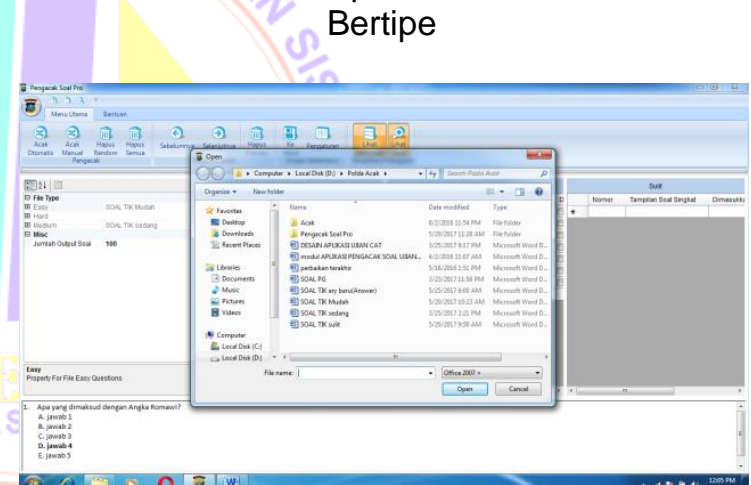

Gambar 16. Tampilan Hasil Load Soal Ms Word Bertipe

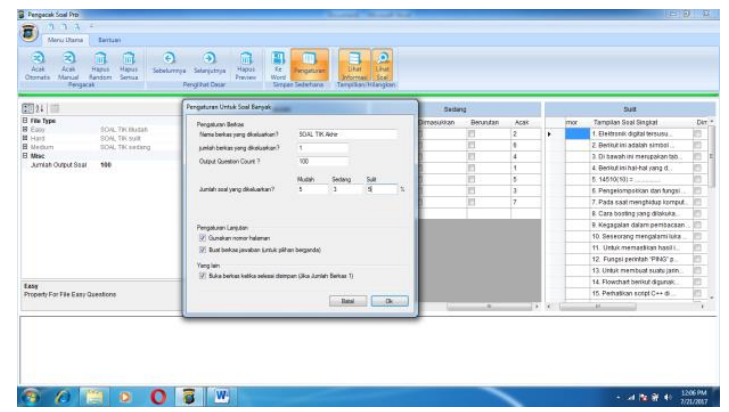

Gambar 17. Tampilan Menentukan Jumlah Soal Ms Word dari masing-masing tipe 

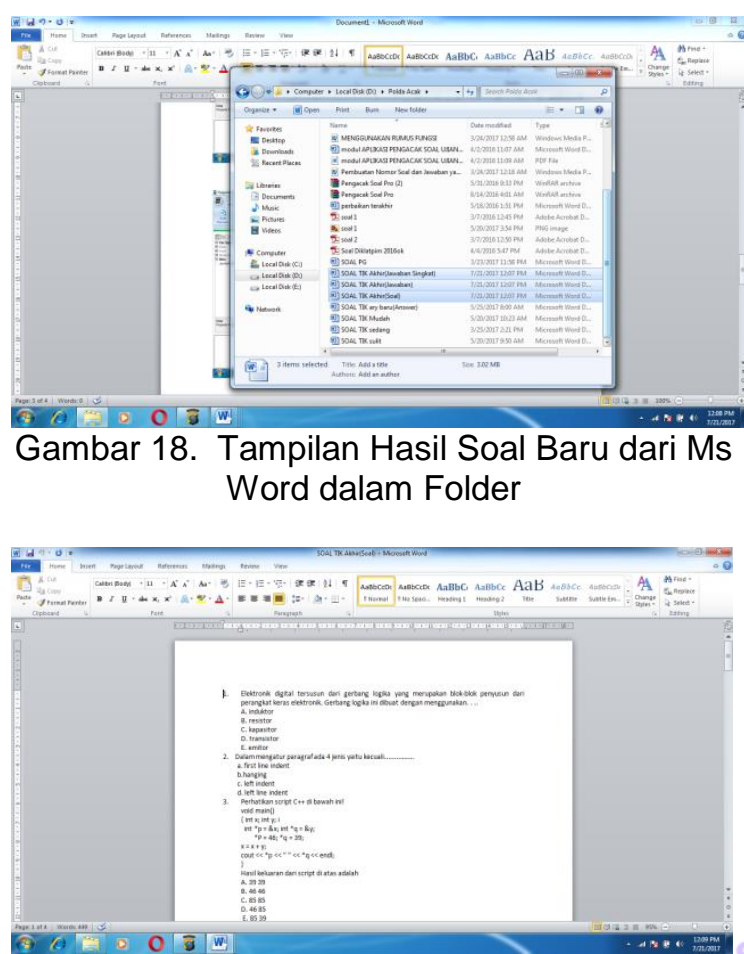

Gambar 19. Tampilan Hasil Soal Baru dari Ms Word

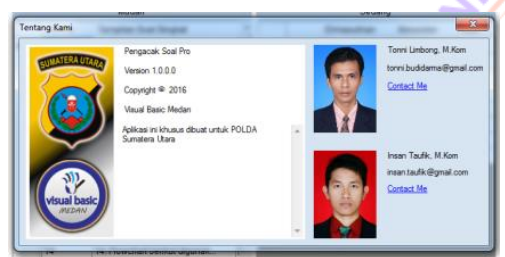

Gambar 20. Tampilan About

2. Millman, Jason and Greene, Jennifer(1993).The Spesification and Development of Tests of Achiievement and Ability in Robert L. Lin (Editor). Educational Measurement, Third Edition. Phoenix: American Council on Education, Series on Higher Education Oryx Press.

3. Ngesti Dania Putri (2014), Sistem Ujian TOEFL Dengan Pengacakan Soal Menggunakan Algoritma Fisher Yates, Program Studi Sistem Informasi di Universitas Jember.

4. Palupi Tria Wardani, Djuniadi(2015), Implementasi Linier Congruent Method Untuk Pengacakan Soal Ujian Pada Aplikasi Belajar Hiragana, jurnal edukomputika semarang.

5. Tonni Limbong, Janner Simarmata (2015),Implementasi Linear Congruent Method (LCM) Untuk Pengacakan Soal Ujian Berkategori, Prosiding seminar Nasional IImu Komputer 2015 (SNIKOM 2015) di Aptikom wilayah I Sumut-NAD.

6. Wright, Benjamin D. and Linacre, John M. (1992). A User's Guide to BIGSTEPS: Rasch Model Computer Program, Version 2.2. Chicago: MESA Press. Wright, B.D. and Stone,

7. http://www.ipulhe.com/pengertian-aplikasi/ tanggal akses 6 April 2016

8. http://www.kompasiana.com/margiyati/kon sep-dan-prosedur-pengembangan-banksoal_5528b767f17e616d7c8b45ce, tanggal akses 6 April 2016

9. https://marlina2.wordpress.com/2011/08/0 7/mengenal-pengembangan-bank-

\section{KESIMPULAN}

Soal yang diketikkan harus sesuai dengan format yang ditentukan agar soal dapat diacak dengan sempurna oleh sistem, sebaiknya jumlah soal dalam bank soal jumlahnya lebih banyak dari jumlah soal yang akan dikeluarkan. Walaupun bank soal yang diketikkan mempunyai format yang tidak pas antara halaman 1 dan lainnya maka jangan di tekan "enter" pada awal soal nomor berikutnya, untuk menurunkannya, akan tetapi biarkan saja tetap seperti itu. Karena akan berpengaruh pada proses pengacakan (nomor berikut itu, belum tentu nanti jadi sesuai urutan). Hasil pengacakan harus tetap dikoreksi, karena mungkin terjadi kesalahan format seperti diatas. Soal gambar dan soal tabel tetap dapat diacak dengan sempurna yang penting pastikan nomor urut soal sesuai jangan sampai ada yang melompat.

\section{DAFTAR PUSTAKA}

1. Jogiyanto, HM (1999), Pengenalan Komputer, Penerbit Andi Jogyakarta 